Review

\title{
An overview of the bioactive compounds, therapeutic properties and toxic effects of apitoxin
}

\author{
Ananias Pascoal $^{\mathrm{a}}$, Maria Manuela Estevinho ${ }^{\mathrm{b}}$, Altino Branco Choupina ${ }^{\mathrm{c}}$, Mário Sousa-Pimenta ${ }^{\mathrm{d}}$, \\ Leticia M. Estevinho ${ }^{\mathrm{a}, \mathrm{c}, *}$ \\ ${ }^{a}$ Mountain Research Center (CIMO), Polytechnic Institute of Bragança, Campus Santa Apolónia, 5300-253, Bragança, Portugal \\ ${ }^{\mathrm{b}}$ Department of Biomedicine, Unit of Pharmacology and Therapeutics, Faculty of Medicine, University of Porto, Porto, Portugal \\ ${ }^{\mathrm{c}}$ Department of Biology and Biotechnology, Agricultural College of Bragança, Polytechnic Institute of Bragança, Campus Santa Apolónia, 5300-253, Bragança, Portugal \\ ${ }^{\mathrm{d}}$ Department of Onco-Hematology, Portuguese Institute of Oncology of Porto (IPO-Porto), 4200-072, Portugal
}

\section{Introduction}

Apitoxin, also known as bee venom (BV), is produced in two specialized abdominal glands of worker bees and is used as a defence weapon of bees' colony (Choi et al., 2015; Zhang et al., 2016). In addition, this natural product has been used since the ancient times to relieve pain and to treat chronic inflammatory diseases such as rheumatoid arthritis, tendinitis, bursitis, skin conditions and even neurologic disorders (Moreno and Giralt, 2015).

This natural product is a light-yellow liquid, characterized by a bitter taste, pungent smell and a pH ranging from 4.5 to 5.5 (Eze et al., 2016; Hossen et al., 2017). Some studies have described that $88 \%$ of BV is water, yet its specific composition varies depending on bee' species and season (Moreno and Giralt, 2015). Indeed, BV has been reported to contain a complex of biologically active compounds among which enzymes (phospholipase $\mathrm{A}_{2}\left[\mathrm{PLA}_{2}\right]$, lysophospholipase, hyaluronidase, acid phosphomonoesterase; $\alpha$-glucosidase, dipeptidyl peptidase IV and vitellogenin), peptides (melittin [MLT], apamin, mast cell degranulating [MCD], mastocytolytic peptide, scapin, adolapin, minimine; apidaecin; tertiapin; melittin F; cadiopep; procamine A, B, pamine, and proteaseinhibitors), biogenic amines (histamine, dopamine, noradrenaline, norepinephrine, neurotransmitters) and other compounds such as amino acids ( $\gamma$-aminobutyric acid, $\alpha$-amino acids), carbohydrates (glucose, fructose), pheromones (Iso-pentyl acetate, n-buttyl acetate, iso-pentanol, n-hexyl acetate, n-octyl acetate, 2-nonanol, n-decyl acetate, benzyl acetate, benzyl alcohol and (2)-11 -eicosen-1-ol) and minerals (P, Ca and Mg) (Nguyen et al., 2015; Tusiimire et al., 2015; Rady et al., 2017; Moga et al., 2018; Lee et al., 2018). Among these compounds, MLT is the main therapeutic ingredient of $\mathrm{BV}$, representing between 40 and $60 \%$ of the dry weight (Abd-Elhakim et al., 2014).

However, it is important to take into account that some BV constituents (such as $\mathrm{PLA}_{2}$, lysophospholipase, hyaluronidase, MLT, apamin and MCD) can exert toxic effects, leading to clinical signs and symptoms of envenomation. On the other hand, other compounds, like phosphatase and $\alpha$-glucosidase, are non-toxic (Cornara et al., 2017).

BV may be obtained from the beehives using electric stunning devices. After, impurities and residues are removed and the remaining purified compound is lyophilized (Han et al., 2013a). In nature, bee venom may be injected into the victims through bees' sting and the amount of venom per sting ranges between 50 and $140 \mu \mathrm{g}$ (Moreno and Giralt, 2015). The responses of the human organism include local and limited or systemic and extensive inflammatory reactions, immune responses and anticoagulant effects (Eze et al., 2016; Cornara et al., 2017).

The most successful drugs developed by the pharmaceutical industry have been isolated from plants, microbes and marine organisms (Ratcliffe et al., 2014). However, only around 900 pharmaceutical products for human usage have been isolated from insects (Hassan et al., 2015). Regarding BV, the majority of the published works are preliminary studies developed in vitro and in vivo using animal models, mostly mice, while little evidence comes from studies performed directly to prove $\mathrm{BV}$ therapeutic activities in humans.

Therefore, this review aims to outline the published literature regarding the pharmacological properties and medical applications of Apitoxin and its bioactive compounds as well as to summarize some of the health concerns related to its application.

\section{Bioactive compounds of bee venom and their biological effects}

Recently, the investigation of bioactive compounds isolated from BV has attracted the attention of several researchers. The majority of the published reports aims to investigate the pharmacological properties of BV components using cell cultures or in animal models, while very little information comes from studies involving humans (Komi et al., 2018). Table 1 summarizes the therapeutic activities of peptides, enzymes and biogenic amines contained in Apitoxin.

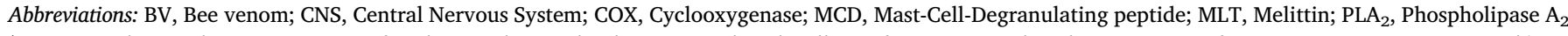
${ }^{*}$ Corresponding author. Department of Biology and Biotechnology, Agricultural College of Bragança, Polytechnic Institute of Bragança, Campus Santa Apolónia, 5300-253, Bragança, Portugal.

E-mail address: leticia@ipb.pt (L.M. Estevinho).
} 
Table 1

Bioactive compounds of bee venom and their implications in human health.

\begin{tabular}{|c|c|c|}
\hline Bioactive compounds & Biological activities & References \\
\hline \multirow[t]{13}{*}{ MLT } & Anti-cancer (solid tumours) & $\begin{array}{l}\text { Li et al. (2006); Liu et al. (2016a); Ip et al. (2012); Jeong et al. (2014); Jin et al. (2018); Jo et al. } \\
\text { (2012); Kong et al. (2016); Mahmoodzadeh et al. (2015); Moreno and Giralt (2015); Rady et al. } \\
\text { (2017); Ratcliffe et al. (2014); Shin et al. (2013); Su et al. (2015); Zarrinnahad et al. (2018); Park et al. } \\
\text { (2010); Lee et al. (2018); Wang et al. (2009); Wang et al. (2017); Zhang et al. (2014); Zhang et al. } \\
\text { (2016) Zhang and Chen (2017) }\end{array}$ \\
\hline & Anti-cancer (hematologic malignancies) & Saini et al. (1999); Moon et al. (2006) \\
\hline & Anti-atherosclerotic & Jeong et al. (2012); Cho et al. (2013) \\
\hline & Anti-arthritis & Jeong et al. (2015) \\
\hline & Anti-inflammatory & $\begin{array}{l}\text { Ip et al. (2012); Jeong et al. (2014); Jin et al. (2018); Jo et al. (2012); Kong et al. (2016); Leandro et al. } \\
\text { (2015); Liu et al. (2016a); Mahmoodzadeh et al. (2015); Moreno and Giralt (2015); Rady et al. (2017); } \\
\text { Su et al. (2015); Zarrinnahad et al. (2018) }\end{array}$ \\
\hline & Antibacterial & $\begin{array}{l}\text { Ip et al. (2012); Jeong et al. (2014); Jin et al. (2018); Jo et al. (2012); Kong et al. (2016); Liu et al. } \\
\text { (2016a); Mahmoodzadeh et al. (2015); Rady et al. (2017); Su et al. (2015); Zarrinnahad et al. (2018); } \\
\text { Leandro et al. (2015); Moga et al. (2018); Shi et al. (2016); Shin et al. (2017) }\end{array}$ \\
\hline & Antiviral & $\begin{array}{l}\text { Hood et al. (2013); Jallouk et al. (2014); Leandro et al. (2015); Moga et al. (2018); Wachinger et al. } \\
\text { (1998) }\end{array}$ \\
\hline & Pro-apoptotic & $\begin{array}{l}\text { Yang et al. (2007); Han et al. (2014); Lee et al. (2014); Leandro et al. (2015); Kim et al. (2018); Moga } \\
\text { et al. (2018) }\end{array}$ \\
\hline & Analgesic & Ahn et al. (2016) \\
\hline & Anti-fibrotic & Shin et al. (2017) \\
\hline & Anti-diabetic & Hossen et al. (2017) \\
\hline & Haemolysis & Tosteson et al., (1985) \\
\hline & Neuro-protective & Han et al. (2014) \\
\hline \multirow[t]{7}{*}{ Apamin } & Antifungal & Shin et al. (2017) \\
\hline & Anti-fibrotic & Park et al. (2014) \\
\hline & Anti-cancer (solid tumours) & Ratcliffe et al. (2014) \\
\hline & Anti-inflammatory & Kim et al. (2017a); Shin et al. (2017) \\
\hline & Anti-atherosclerotic & Kim et al. (2015) \\
\hline & Antibacterial & Leandro et al. (2015) \\
\hline & Suppresses biliary fibrosis & Kim et al. (2017b) \\
\hline \multirow[t]{7}{*}{$\mathrm{PLA}_{2}$} & Antibacterial & Boutrin et al. (2008); Leandro et al. (2015) \\
\hline & Anti-arthritis & Eze et al. (2016) \\
\hline & Anti-trypanosomiasis & Boutrin et al. (2008) \\
\hline & Neuroprotective & Jeong et al. (2011) \\
\hline & Anti-malarial & Deregnaucourt and Schrével (2000) \\
\hline & Anti-cancer & Ratcliffe et al. (2014); Wang et al. (2009) \\
\hline & Anti-HIV & Fenard et al. (2001), Ratcliffe et al. (2014) \\
\hline \multirow[t]{4}{*}{ Secapin } & Antifungal & Lee et al. (2016a) \\
\hline & Antibacterial & \\
\hline & Anti-elastolytic & \\
\hline & Anti-fibrinolytic & \\
\hline \multirow[t]{3}{*}{ Adolapin } & Anti-inflammatory & dos Santos-Pinto et al. (2018); Moga et al. (2018); Nitecka-Buchta et al. (2014); Komi et al. (2018) \\
\hline & Anti-nociceptive & \\
\hline & Anti-pyretic & \\
\hline Apidaecin & Antibacterial & Li et al. (2006a); Van Vaerenbergh et al., (2013) \\
\hline \multirow[t]{3}{*}{ Protease inhibitor } & Antibacterial & Eze et al. (2016) \\
\hline & Anti-inflammatory & \\
\hline & Haemostasis & \\
\hline Tertiapin & Inward-rectifier $\mathrm{K}^{+}$channel block & Cornara et al. (2017) \\
\hline \multirow[t]{7}{*}{ Cardiopep } & Beta adrenergic blocker, anti-arrhythmic & Moreno and Giralt (2015); Vick et al. (1974) \\
\hline & Mast cell degranulation, histamine release & Moga et al. (2018) \\
\hline & Anti-inflammatory & Eze et al. (2016); Moreno and Giralt (2015) \\
\hline & Allergic response and Hypersensitivity & dos Santos-Pinto et al. (2018) \\
\hline & Enhance the noxious action of substances & Reitinger et al. (2008) \\
\hline & Use in BV immunotherapy & Hossen et al. (2016) \\
\hline & $\begin{array}{l}\text { Embryogenesis; angiogenesis, diffusion of toxins } \\
\text { and drugs, metastasis }\end{array}$ & Bordon et al. (2015) \\
\hline \multirow[t]{2}{*}{ Histamine } & Allergic response & Eze et al. (2016) \\
\hline & Local and systemic inflammation & \\
\hline
\end{tabular}

\subsection{Peptide components}

\subsubsection{Melittin}

Melittin (MLT), also known as allergen Api m4 (Hossen et al., 2017), is the main compound of $\mathrm{BV}$, comprising approximately $40-60 \%$ of its dry weight. MLT (together with apamin) has been reported to be found only in bee venom produced by the genus Apis (Moreno and Giralt, 2015). It is a linear, amphipathic, cationic and a-helical polypeptide molecule composed of 26 amino acid residues and is soluble in water (Silva et al., 2015; Kachel et al., 2018).

Recent studies provided evidence on several biological properties of MLT (Table 1). MLT has been reported to be a very potent anti- inflammatory agent, being 100 times more potent than hydro-cortisol in animal models (Vick and Shipman, 1972; Eze et al., 2016). The antiinflammatory activity of this compound has been explored in several settings, including acne vulgaris, neuro inflammation, atherosclerosis, arthritis and liver inflammation (Lee and Bae, 2016).

Its ability to disrupt lipid cell membranes and antimicrobial properties has also attracted great interest, especially for the treatment of drug-resistant infections (Choi et al., 2015; Cornara et al., 2017; Nguyen et al., 2015; Uddin et al., 2016). These authors also observed that MLT significantly inhibits the replication of both enveloped [melittin molecules fuses with viral envelope, forming pore-like attack complexes] and non-enveloped viruses, decreasing their infectivity 
through surface charge interaction.

This compound is also cytotoxic against cancer cells among other mechanisms through the activation of apoptotic pathways (both caspase-dependent and caspase-independent) and PLA 2 pathways (Lee et al., 2018; Jin et al., 2018; Shin et al., 2017; Zhang and Chen, 2017; Wang et al., 2017). Indeed, the growth inhibitory potential and the capacity to suppress tumour metastasis of MLT has been observed in several types of cancer cells like liver, renal, prostate, breast, lung, bladder, gastric and leukemia, suggesting that it may be a potent agent to use in chemotherapy (Liu et al., 2016; Moreno and Giralt, 2015; Kong et al., 2016).

Melittin has also been shown to induce neural plastic changes in pain-signalling pathways by sensitization and activation of nociceptor cells (Wehbe et al., 2019).

A schematic representation of the action mechanisms of some biological effects of MLT (anticancer, anti-inflammatory, antimicrobial and anti-nociceptive) are presented in Fig. 1.

In spite of the promising properties that are attracting much interest from pharmacological and biotechnological fields, MLT (whose initial structure is helical, when embedded in a lipid bilayer) can change to a dimeric form that destabilizes and alters artificial lipid bilayers containing dioleoylphosphatidylcholine (Somwongin et al., 2018). Therefore, MLT may induce morphologic changes in a dose-dependent manner, being a nonselective cytolytic peptide that may induce the lysis of red blood cells and human peripheral blood lymphocytes, among others (Gajski et al., 2016). Indeed, while in small doses MLT has antiinflammatory effects, increases capillary permeability, in higher doses it may cause inflammation, itching, irritation and local pain (Lee and Bae, 2016). According to the literature, this compound may cause slight, moderate and severe irritation at $0.5 \mathrm{mg} / \mathrm{ml}, 1 \mathrm{mg} / \mathrm{ml}$ and concentrations above $2 \mathrm{mg} / \mathrm{ml}$, respectively (Somwongin et al., 2018). The mechanism underlying toxicity is based in the disruption of phospholipid bilayers which lead to mast cells' lysis and the release of compounds like lysosomal enzymes, histamine and serotonin, triggering pain and inflammation. Therefore, MLT together with hyaluronidase and $\mathrm{PLA}_{2}$, are responsible for venom allergenic properties breaking up membranes cells and enhancing their cytotoxic effect (Kachel et al., 2018).

Attempts have been made to avoid these side effects via phosphorylation of MLT in specific amino acid residues; the peptide phosphorylated in ${ }^{18}$ Ser elicited lower allergenic responses when compared to native melittin. In addition, ongoing studies are assessing MLT incorporation into nanoparticles in order to decrease its the nonspecific lytic activity (Abd El-Wahed et al., 2018).

\subsubsection{Apamin}

Apamin is a neurotoxin with 18 amino acid residues that comprises 2-3\% of BV dry weight (Rady et al., 2017; Moga et al., 2018). As mentioned previously, apamin and MLT are "specie specific" compounds whose presence has only been reported in the BV of the Apis genus (Moreno and Giralt, 2015). Apamin is permeable to the blood-brain barrier, affecting the central nervous system (CNS) and producing hyperactivity and convulsions. It is well known that this peptide is as a specific and high-affinity blocker of small-conductance $\mathrm{Ca}^{2+}$-activated K+ channels (SK-channels) (Kim et al., 2017a; Zhang et al., 2018). Peripherically, apamin selectively and potently affects the potassium permeability of muscle cells membranes and, when in high doses, may cause muscle spasms and respiratory failure. This characteristic has been widely explored and apamin has been used in the literature to identify the activity of the SK-channels in different cells such as visceral smooth muscle, microglial cells, adrenal cortex, hepatocytes and ventricle cells (Voos et al., 2017). In spite of this, recent studies demonstrated that this compound is also capable of inhibiting the channel Kv1.3 with high affinity (Voos et al., 2017). These two types of channel are frequently co-expressed in different tissues among which immune system cells ( $\mathrm{T}$ cells, macrophages and dendritic cells).

Several researchers studied health-related applications of Apamin (Table 1) as anti-inflammatory (Shin et al., 2017), antibacterial, antifungal, anti-fibrotic (Shin et al., 2017), anti-cancer (Ratcliffe et al., 2014), anti-atherosclerosis (Kim et al., 2015), anti-nociceptive and

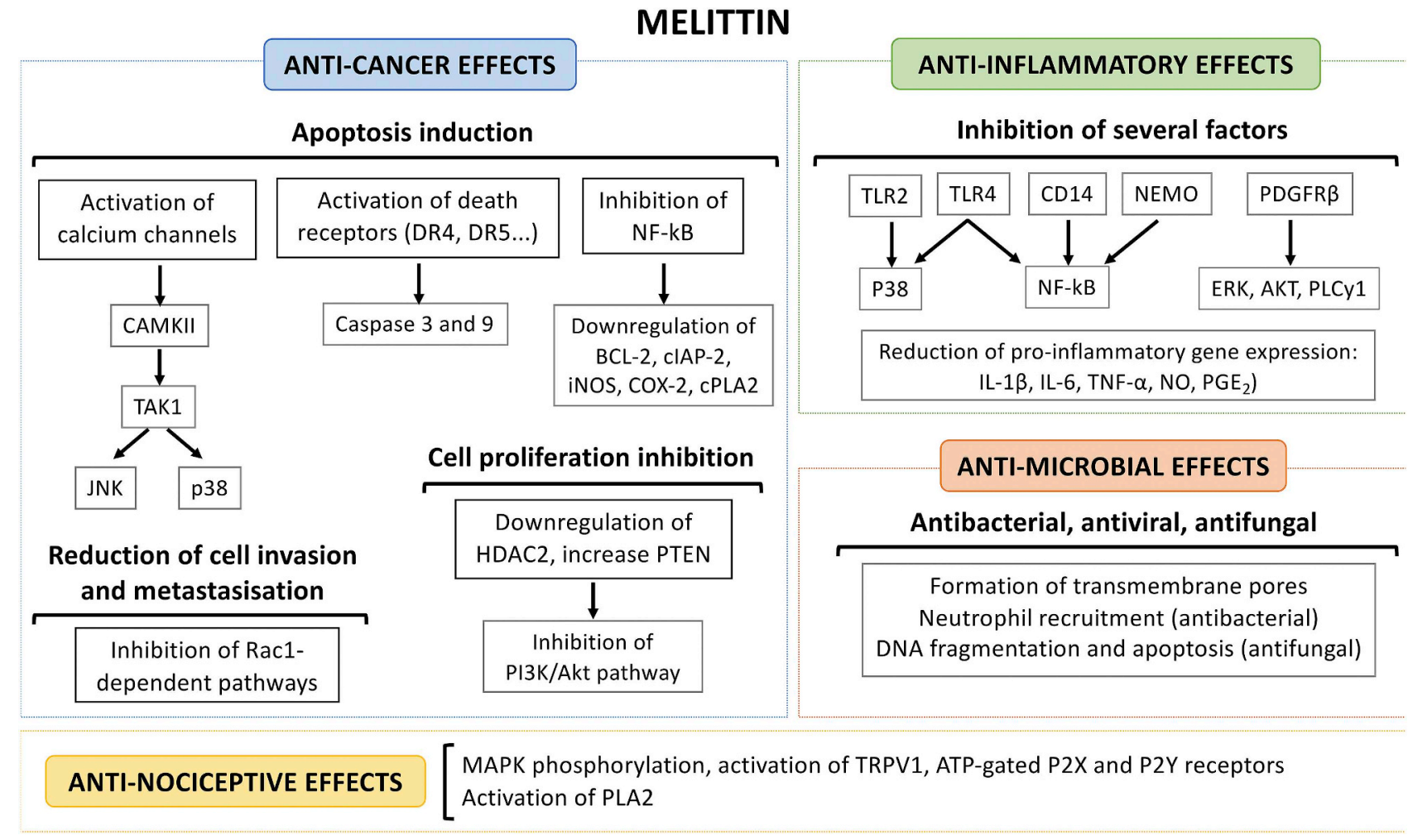

Fig. 1. Schematic representation of the action mechanisms of some biological effects of melittin. 
cytotoxic against cancer cells (Son et al., 2007). It has also been reported to protect undamaged neurons but also to be able to restore the function of silent ones (Moreno and Giralt, 2015). In mice models with cholestatic liver disease apamin suppressed the deposition of collagen and the expression of fibrogenic genes (Kim et al., 2017b), suggesting its role has a potential therapeutic target.

\subsubsection{Mast-cell-degranulating peptide}

Mast cell degranulating (MCD), also known as peptide 401, (Cherniack and Govorushko, 2018), is another important compound with 22 amino acids and two disulphide bridges which comprises around 3\% of BV dry weight. It promotes mast-cells degranulation, triggering inflammatory reactions (Rady et al., 2017; Komi et al., 2018). MCD has unique immunologic properties, causing histamine release at concentrations of less than $0.1 \mathrm{mg} / \mathrm{mL}$ while acting as an antiinflammatory compound at higher concentrations (Moga et al., 2018). Indeed, MCD has been recognized as a potent anti-inflammatory agent (Moreno and Giralt, 2015). This compound is also a neurotoxin by blocking fast-inactivating and slow-inactivating calcium-activated potassium channels (KC-channels), therefore increasing neuronal excitability (Cornara et al., 2017). However, the effects in the CNS are poorly studied (Chen et al., 2016).

\subsubsection{Secapin}

Secapin, comprising only $0.5-2 \%$ of BV dry weight, is a potent neurotoxin containing 25 amino acid residues and a disulphide bridge between Cys 9 and Cys 20 (Rady et al., 2017). It is a serine protease inhibitor-like peptide with anti-fibrinolytic (plasmin inhibitor), antielastolytic, anti-fungal and antibacterial activities; nevertheless, the mechanisms underlying such actions are poorly understood (Lee et al., 2016).

\subsubsection{Adolapin}

Adolapin is a basic polypeptide with 103 amino acid residues, represenitng $0.5-1 \%$ of BV dry weight matter (Rady et al., 2017). This compound has been reported to be anti-inflammatory, anti-nociceptive and anti-pyretic, mainly due to the inhibition of cyclooxygenase (COX), $\mathrm{PLA}_{2}$ and lipoxygenase, thereby, prostaglandin synthetase system, following a biphasic dose-response relationship (Moga et al., 2018; Nitecka-Buchta et al., 2014; Komi et al., 2018).

\subsubsection{Apidaecin}

Apidaecin-type peptides are a series of small proline-rich peptides containing 18 to 20 amino acid residues (Li et al., 2006a). This nonhelical and heat-stable compound is active against a wide range of human pathogens and plant-associated bacteria, through a bacteriostatic process (Van Vaerenbergh et al., 2013). These compounds are the largest group of proline-rich antimicrobial peptides known to date and appear to be non-toxic to human and animal cells, making them potential candidates for the development of new antimicrobials in the future (Li et al., 2006a).

\subsubsection{Protease inhibitor}

The protease-inhibitor comprises $0.1-0.8 \%$ of BV dry weight and has been reported to have anti-inflammatory and anti-fibrinolytic effects (Eze et al., 2016). Other studies revealed anti-microbial activity against fungi, gram-positive and gram-negative bacteria (Yang et al., 2017).

\subsubsection{Tertiapin}

Tertiapin comprises $<0.1 \%$ of BV dry weight and is a small presynaptic peptide with 21 amino acids that blocks inward rectifier KC channels expressed in heart, epithelial cells and CNS (dos Santos-Pinto et al., 2018; Rady et al., 2017). Despite being classified as a neurotoxin (as occurs for MCD and secapin), the information on its pharmacological and toxicological effects in the CNS is quite limited (Chen et al.,
2016). Nowadays, tertiapin is used only for $\mathrm{K}^{+}$channel modulation; in the future it is expected to be useful for treating disorders in atrioventricular transmission (Cornara et al., 2017).

\subsubsection{Cardiopep}

Cardiopep is a peptide comprising less than $0.7 \%$ of BV dry matter (Moreno and Giralt, 2015) reported to possess beta adrenergic and antiarrhythmic effects (Vick et al., 1974).

\subsubsection{Other peptides}

Other minor constituents of BV are pamine (1-3\% of dry weight matter), minimine (2\%), procamine $\mathrm{A}, \mathrm{B}(1-2 \%)$, and melittin $\mathrm{F}$, a fragment of MLT in which the first seven residues from the $\mathrm{N}$ terminus are missing $(<0.1 \%)$ (Chen et al., 2016; Rady et al., 2017).

\subsection{Proteins}

\subsubsection{Phospholipase $A_{2}$ (EC 3.1.1.4)}

Phospholipase $\mathrm{A}_{2}$ has been reported to be the most abundant enzyme of BV, corresponding to $10-12 \%$ of its dry weight matter (dos Santos-Pinto et al., 2018). Due to its high molecular weight and strong antigenicity, this enzyme has been pointed as the major cause of the systemic allergic reactions to BV (Gajski et al., 2016; Hossen et al., 2016). On the other hand, several recent reports unveiled the potentiality of $\mathrm{PLA}_{2}$ in the treatment of human disorders (Table 1) including Parkinson's disease, asthma, several types of cancer, as well as immune mediated disorders like cisplatin-induced nephrotoxicity, hepatotoxicity and Lupus nephritis (Ratcliffe et al., 2014). Its role in bacteria and parasite infections was also described. For instance, Boutrin et al. (2008) observed that PLA 2 inhibited Gram-negative bacteria and the parasitic protozoan Trypanosoma brucei. This study also confirmed the antibacterial activity against Escherichia coli, Enterobacter cloacae and Citrobacter freundii (Boutrin et al., 2008), Burkholderia pseudomallei, Staphylococcus aureus, Streptococcus salivarius and Lactobacillus casei.

\subsubsection{Hyaluronidase (EC 3.2.1.35)}

Hyaluronidase is widely distributed in nature, particularly in animal venoms such as bee, scorpion, wasp, spider, fish and crustaceans (Bordon et al., 2015). This enzyme is composed by 350 amino acids and specifically degrades hyaluronic acid in the extracellular matrix of skin matrix, allowing the penetration of venom components deeply into the blood stream (Marković-Housley et al., 2000). Other roles of hyaluronidase in envenoming process are cell membrane disruption, pore formation, mast cell degranulation (dos Santos-Pinto et al., 2018), dilatation and increased permeability of blood vessels (Hossen et al., 2016). This enzyme is the second major allergen of BV (following Phospholipase $A_{2}$ ), comprising $1-2 \%$ of dry weight matter (Cornara et al., 2017). Even though hyaluronidase has little toxicity it can enhance the effect of other toxins present in venoms, contributing to the local and systemic effects of envenoming (Bordon et al., 2015).

Regarding the application of hyaluronidases for human health, these may act as an adjuvant to enhance the absorption and dispersion of injected drugs, be used in ophthalmologic surgeries and in the treatment of diseases associated with excessive "ground substance", either applied subcutaneously or in a topical way (Reitinger et al., 2008). These enzymes may also play a role in various physiological mechanisms like angiogenesis, embryogenesis, metastasis formation, cicatrisation and in several inflammatory settings like pneumonia, meningitis and sepsis (Bordon et al., 2015).

\subsubsection{Acid phosphomonoesterase (EC 3.1.3.2)}

The acid phosphomonoesterase, also known as acid phosphatase, is a glycoprotein and potent allergen found in BV, representing approximately $1-2 \%$ of its dry weight matter (Rady et al., 2017). This compound has been reported as a stronger elicitor of histamine release from basophils of sensitized humans. However, the pathophysiological role 
of this enzyme following BV inoculation remains largely unexplored. Even so, some reports exist regarding the potential for immunotherapy against BV (Hossen et al., 2016).

\subsubsection{Dipeptidyl peptidase IV}

Dipeptidyl peptidase IV (Api $\mathrm{m}$ 5) is present in BV in low concentrations ( $<1 \%$ of dry weight) and has been identified as one of the proteins of higher molecular weight $(102 \mathrm{kDa})$. It appears to be responsible for the cross-reactivity between bees and wasps' venoms (Antolín-Amérigo et al., 2017).

This proteolytic enzyme cleaves $\mathrm{N}$-terminal dipeptides from polypeptides with proline or alanine in the penultimate position, what leads to the activation of BV components and promotes hypersensitivity reactions (dos Santos-Pinto et al., 2018).

\subsubsection{Vitellogenin}

Vitellogenin is another allergen found in BV, present in larger amounts in the BV secreted by honeybee queens. This enzyme is believed to be involved in several processes such as hormone signalling, food-related behaviour, stress resistance, immunity and longevity (dos Santos-Pinto et al., 2018), yet the underlying mechanisms remain unclear (Blank et al., 2013). Its role in the hypersensitive reactions has also been reported (dos Santos-Pinto et al., 2018).

\subsubsection{Other proteins}

Several proteins are present in BV in low concentrations, comprising $<1 \%$ of its dry weight matter: Lysophospholipase (EC 3.1.1.5) also known as phospholipase B (Hossen et al., 2016; Rady et al., 2017) and $\alpha$-D-Glucosidase (EC 3.2.1.20) (Hossen et al., 2016; Rady et al., 2017). To date, their biological activities are poorly documented.

\subsection{Biogenic amines}

\subsubsection{Histamine}

This small molecule comprises $0.5-2 \%$ of BV dry weight matter and is the major component among the category of biogenic amines (Moreno and Giralt, 2015). During bee venom allergy, histamine is the principal inflammatory mediator released immediately in the skin, mainly mediated by mast cell degranulation peptide. This amine promotes capillary leakage, causes itching, swelling and pain (Rady et al., 2017).

\subsubsection{Dopamine and noradrenaline}

Dopamine and noradrenaline are also low molecular weight compounds found in $\mathrm{BV}$ comprising $<1 \%$ of its dry weight matter (Rady et al., 2017). These compounds are ionotropic agents and have been pointed out to be protease inhibitors, playing a role in haemostasis and acting as anti-inflammatory agent (Nitecka-Buchta et al., 2014).

\subsection{Other components}

BV also contains amino-acids (like $\gamma$-aminobutyric acid and $\alpha$-amino acids), carbohydrates and pheromones (iso-pentyl acetate, n-butyl acetate, iso-pentanol, n-hexyl acetate, n-octyl acetate, 2-nonanol, ndecyl acetate, benzyl acetate, benzyl (Rady et al., 2017).

\section{Therapeutic applications of bee venom in human health}

The use of bee products (honey, pollen, propolis, bees' wax, royal jelly and bee venom) to treat some human illnesses is known as apitherapy and dates back from thousands of years, with their healing properties being cited in many religious texts (Cornara et al., 2017). BV has been used since around 3000 BC in ancient Egypt and Greece (Yang et al., 2017; Lee et al., 2018). Throughout the decades the use of apitherapy expanded from the Eastern to the Western countries, being currently practiced all over the world (El-Wahab and Eita, 2015), mostly as a complement to the conventional medicine practices. Notwithstanding, the understanding of the chemical composition and actions of BV dates back only 50 years ago (Moreno and Giralt, 2015).

Depending on the health condition under treatment BV can be used topically (by applying a cream, liniment, or ointment), via injection, either through acupuncture or directly through a live bee sting. Currently, the most commonly used method is BV acupuncture, which consists in the injection of diluted bee venom into acupuncture points (Lee et al., 2015).

In the last decade, as result of increasing investigation worldwide, the usefulness of BV has been reported for several diseases and pathologic contexts (Table 2), in studies performed in vitro and in vivo, in animal models or enrolling humans. Among other settings, the effects of BV were demonstrated in multiple sclerosis and Parkinson's disease (Ostrovsky and Ehrlich, 2018), dementia (Silva et al., 2015), atherosclerosis (Lee and Bae, 2016), osteoarthritis (Lee et al., 2012), human immunodeficiency virus (HIV) (Jallouk et al., 2014), periodontitis (Gu et al., 2019), Diabetes mellitus (Hossen et al., 2017) and rheumatoid arthritis (Son et al., 2007; Brito et al., 2018). The effects of BV and its isolated bioactive compounds have also been described in several types of solid cancer like breast, ovarian, bladder, lung, liver and prostate, as well as on hematologic malignancies (Moga et al., 2018). Other therapeutic activities described are antibacterial, anti-fibrosis and antinociceptive (Cho et al., 2018; Cornara et al., 2017). One of the best documented effects of BV is its powerful anti-inflammatory activity, which is particularly due to the presence of melittin. Indeed, even though BV may produce local inflammation when delivered in high doses, when used in controlled concentrations it has potent anti-inflammatory effects by influencing endogenous cortisol production and suppressing inflammatory mediators among which tumour necrosis factor alpha (TNF- $\alpha$ ) and interleukin $1-\beta$ (Lee and Bae, 2016). This property is very relevant having into account the important role of chronic inflammation in the pathogenesis of a wide range of conditions like cardiovascular diseases, obesity and diabetes, asthma, autoimmune disorders, inflammatory bowel disease and neurological diseases.

In addition, due to its anti-ageing properties, BV has been increasingly more used in the manufacture of cosmetics products (Choi et al., 2015). All of these biological activities are related to the presence of some bioactive compounds mainly the MLT, PLA 2 apamin, secapin, tertiapin and MCD (Zarrinnahad et al., 2018).

In this context, this natural product and its isolated components are valuable resources to be used in the future for the design and development of drugs. However, besides the fact that the BV concentration that allows maximising the beneficial effects while decreasing the adverse ones remains unknown, many of the active compounds are far from being explored (Uddin et al., 2016). In addition, the toxicity of BV remains a big dilemma for researchers and clinicians; indeed, while small compounds and peptides mainly mediate local reactions causing discomfort, larger proteins are involved in direct tissue damage or in systemic hypersensitive reactions including anaphylaxis (Jakob et al., 2017). Thereby, yet much information is available regarding the potential applications of BV, further studies must be developed to clarify the optimum dose, its adverse effects (particularly on risk groups like pregnant and breast-feeding women) and the possible interactions with conventional drugs. A graphical overview of current strengths, weaknesses, opportunities and threats of bee venom is depicted in Fig. 2.

\section{Applications of bee venom in the cosmetic industry}

BV has several promising properties that aroused the interest of the dermatocosmetic industry (Komi et al., 2018). Indeed, besides its antimicrobial, antibacterial and anti-inflammatory properties, some studies reported the potentiality of BV to reduce skin aging manifestations such as skin tone changes, wrinkles, sagging and evenness (Choi et al., 2015). Notwithstanding, the potential to cause skin irritation could be a major concern (Somwongin et al., 2018). 
Table 2

Pharmacological activities and medical applications of Apitoxin.

\begin{tabular}{|c|c|}
\hline Effects of bee venom & References \\
\hline Amyotrophic lateral sclerosis & Lee and Bae (2016) [in vivo, animal models] \\
\hline Anti-ageing & $\begin{array}{l}\text { Choi et al. (2015) [in vivo, humans; in vitro]; Han et al. (2013a) [in vivo, humans; in vitro]; Tusiimire et al. (2015) [in vitro]; Han } \\
\text { et al. (2015) [in vivo, humans; in vitro]; Lee et al. (2015) [in vitro] }\end{array}$ \\
\hline Anti-arthritic & Lee et al. (2012); Wang et al. (2002); Jeong et al. (2015); Son et al. (2007) [all studies performed in vivo, in humans]; \\
\hline Anti-dandruff & Prakash and Bhargava (2014) [in vitro] \\
\hline Anti-fibrotic & Lee et al. (2015) [in vivo, animal models] \\
\hline Anti-inflammatory & Sobral et al. (2016); Kim et al. (2016); Mohammadi et al. (2015) [all performed in vitro] \\
\hline Anti-nociceptive & Cornara et al. (2017); Son et al. (2007) [both in vitro] \\
\hline Anti-atherosclerotic & Moreno and Giralt (2015); Lee and Bae (2016) [both in vitro] \\
\hline Anticancer (hematologic malignancies) & Safaeinejad et al. (2013) [in vitro]; Mohseni-Kouchesfahani et al. (2017); Moga et al. (2018) [all performed in vitro] \\
\hline Anticancer (solid tumours) & $\begin{array}{l}\text { Son et al. (2007); Liu et al. (2016); Park et al. (2011); Cornara et al. (2017); Ip et al. (2008); Jo et al. (2012); Kim et al. (2015a); } \\
\text { Oršolić (2009); Choi et al. (2014); Gajski et al. (2016); Tu et al. (2008); Lee et al. (2015b); Wang et al. (2015); Sisakht et al. } \\
\text { (2017); Jung et al. (2018); Moga et al. (2018) [all performed in vitro] }\end{array}$ \\
\hline Antidiabetic & Prakash and Bhargava (2014) [in vivo, humans]; Hossen et al. (2017) [in vivo, mice and rabbits]; \\
\hline Antimicrobial & Han et al. (2016); Lee (2016); Hegazi et al. (2017); Al-Safar et al. (2018); Park et al. (2018) [all performed in vitro] \\
\hline Antimutagenic & Varanda et al. (1999); Cornara et al. (2017) [all performed in vitro] \\
\hline Antioxidant & Sobral et al. (2016); Somwongin et al. (2018) [all performed in vitro] \\
\hline Antiproliferative and cytotoxic & Gülmez et al. (2017); Sobral et al. (2016) [all performed in vitro] \\
\hline Antiviral & Hassan et al. (2015); Hood et al. (2013); Kim et al. (2015a); Wachinger et al. (1998), Jallouk et al. (2014) [all performed in vitro] \\
\hline Apoptosis & $\begin{array}{l}\text { Moon et al. (2006); Jang et al. (2003); Park et al. (2014); Ip et al. (2008); Doo et al. (2012); Choi et al. (2014); Sisakht et al. } \\
\text { (2017) [all performed in vitro] }\end{array}$ \\
\hline Alleviating post-stroke shoulder pain & Cho et al. (2013a) [in vivo, humans] \\
\hline Chemotherapy-induced peripheral neuropathy & Park et al. (2012); Yoon et al. (2012) [in vivo, humans] \\
\hline Chronic osteoarticular pain & Shin et al. (2012); Seo et al. (2017) [in vivo, humans] \\
\hline Complex regional pain syndrome & Kim et al. (2014) [in vivo, humans] \\
\hline Depression & El-Wahab et al. (2015); Cherniack and Govorushko (2018) [in vivo, humans] \\
\hline Lateral epicondylitis of the elbow & Jung et al. (2014) [in vivo, humans] \\
\hline Neuro-protective & Doo et al. (2012); Jung et al. (2015); Hwang et al., 2015 [all performed in vitro] \\
\hline Parkinson's disease & Cho et al. (2018); Hwang et al., 2015; Ostrovsky and Ehrlich (2018); Kim and Jeon (2014); Lee and Bae (2016) [in vivo, humans] \\
\hline Periodontitis & Kim et al. (2018); Gu et al. (2019) [both in vitro] \\
\hline Postherpetic neuralgia & Lee et al. (2014a) [in vivo, humans] \\
\hline Radio-protective & Cornara et al. (2017); Gajski et al. (2016) [in vitro] \\
\hline Rheumatoid arthritis & Son et al. (2007); Lee et al. (2003); Lee et al. (2003a); Brito et al. (2018) [all performed in vivo, using animal models] \\
\hline Sexual dysfunction & Lee and Yu (2014) [in vivo, humans] \\
\hline Skin disease (acne vulgaris) & Han et al. (2013a); Han et al. (2016a); Kim et al. (2015) [in vitro, in humans]; \\
\hline
\end{tabular}

\section{APITOXIN}

Molecular formula: $\mathrm{C}_{129} \mathrm{H}_{224} \mathrm{~N}_{38} \mathrm{O}_{31}$

\section{Global composition}

$88 \%$ water; the remaining $22 \%$ follow the distribution:

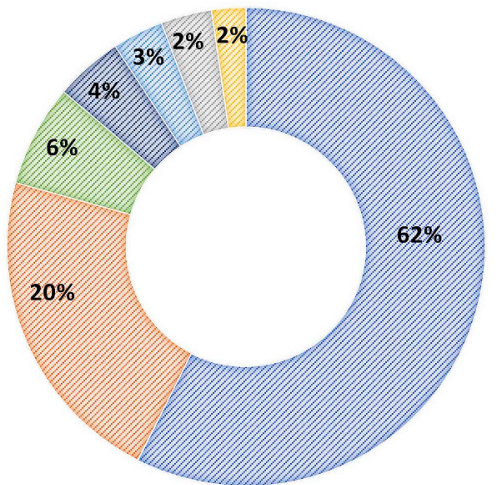

Peptide components $\sim 62 \%$

Melittin $~ 50 \%$

Mast cell degranulating peptide 3\%

Proteins $\sim 20 \%$

Phospholipase A2 11\%

Hyaluronidase $\sim 2 \%$

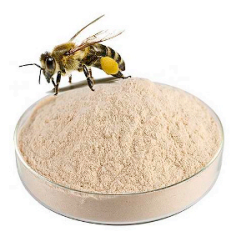
compounds present several biological activities (detailed in Tables 1 and 2).

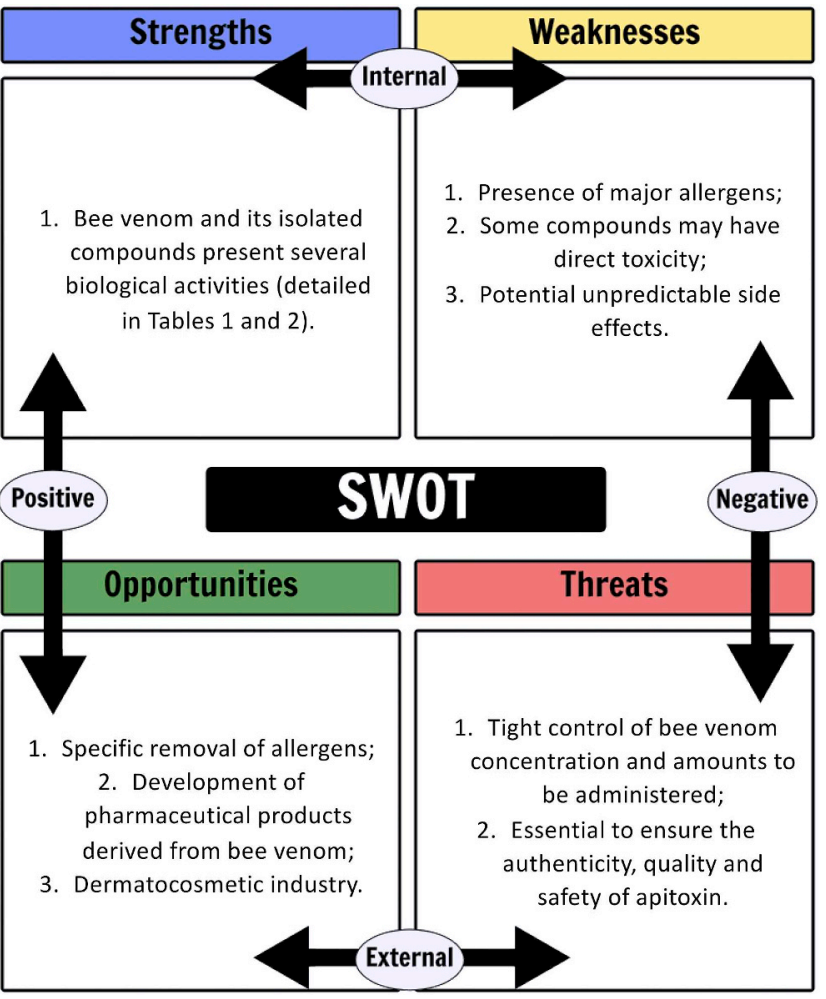

Fig. 2. Graphical overview of apitoxin composition, strengths, weaknesses, opportunities and threats. 
Han et al. (2013a) observed that cosmetics containing purified BV had a better efficiency in reducing microorganisms' concentration and the number of skin lesion, suggesting that purified BV could be a good candidate for developing new formulations for acne vulgaris treatment. Later, Han et al. (2015) made it possible to objectify BV efficacy in terms of reducing wrinkle count, area, and depth in subjects with photodamaged skin. Also, these authors stated that the irritation potential is negligible and that long-term treatment with bee venomcontaining cosmetics was safe.

Current, the majority of the cosmetic products available on the market do not mention exactly the content of BV, being marketed as containing "purified bee venom" or "bee venom extracts" without further specification. Efforts must be done in order to invest in products' standardization and labelling, in order to overcome this very important limitation. Indeed, a method for the detection and quantification of melittin, as a marker of BV concentration, was developed by Tusiimire et al. (2015).

\section{Bee venom: safety and practical considerations}

During the bee sting a small amount of BV is injected into the victim (maximum of $0.3 \mathrm{mg}$ per sting). The severe allergic reactions, which among insects are most frequently induced by the order hymenoptera, are more often related to IgE-mediated reactions induced by allergens rather than to the direct toxic activity of other venom components (dos Santos-Pinto et al., 2018). To date, the main allergens found in BV are phospholipase A2 (Api m1), hyaluronidase (Api m2), acid phosphomonoesterase (Api m3), melittin (Api m4), dipeptidyl dipeptidase IV (Api m5), protease inhibitor (Api m6), CUB serine protease 1 (Api m7), carboxylesterase (Api m8), serine carboxypeptidase (Api m9), icarapin (Api m10), major royal jelly protein 9 (Api m 11.0101 \& Api m 11.0201) and vitellogenin (Api m12) (Kołaczek et al., 2017). According to the International Union of Immunological Societies (IUIS), Phospholipase $A_{2}$, hyaluronidase and apamin are the major allergens contained in BV (Tusiimire et al., 2015; Park et al., 2013; Lee et al., 2018). These compounds induce changes in cell membranes, degrade hyaluronic acid, enhance toxins' spreading into tissues and play a role in the destruction of extracellular matrix, among other mechanisms (Reitinger et al., 2008).

According to the literature, more than $50 \%$ of the general population has IgE reactivity to the major allergens of BV which can cause a spectrum of allergic reactions, which usually appear within $10 \mathrm{~min}$ (Vazquez-Revuelta and Madrigal-Burgaleta, 2018). The reactions induced by BV affect the skin but also the gastrointestinal, respiratory and cardiovascular systems, ranging from mild, local swelling to systemic and severe reactions that in some cases can even be life-threatening (Marković-Housley et al., 2000).

Even though it has been reported that venom immunotherapy is effective in the majority of Hymenoptera venom allergic patients, early and late side effects to the injections have been found in $20-40 \%$ of the patients (Blank et al., 2013). The most common early side effect is the acute local reaction, followed by weakness and dyspnoea; rhinitis and abdominal pain are more common as late side effects (Kołaczek et al., 2017).

In order to ensure patients' safety and to take advantage of the potentialities of $\mathrm{BV}$ while reducing the side effects, some researchers suggest the removal of the allergens $\mathrm{PLA}_{2}$, hyaluronidase, acid phosphomonoesterase and apamin (Brito et al., 2018). In that context, Lee et al. (2018) developed an effective strategy for MLT purification from BV which also effectively removed PLA P $_{2}$ and apamin. Also, Park et al. (2013) found that the use of $50 \%$ ethanol aqueous solution for the purification and analysis of BV, the content of apamin and other allergens was significantly decreased, yet MLT was kept stable. In addition, Lee et al. (2015c) and Brito et al. (2018), by means of ultrafiltration using $10 \mathrm{kDa}$ molecular weight cut-off filters, made it possible to effectively remove $\mathrm{PLA}_{2}$.
Even though BV has promising healing properties it may cause several adverse events, whose occurrence is mostly unpredictable. Local inflammatory but also systemic reactions, among which erythema, pruritus, swelling, pain, anaphylaxis, neurological complications among other nonspecific reactions may occur (Yang et al., 2017). Therefore, the researchers and health care practitioners must be aware and pay careful attention to the safety rules regarding the BV concentration and amounts to be administered in the patients (Zhang et al., 2018).

The beehive products have been used in the human therapeutic activities since memorable times. Concretely, the practices of acupuncture using the venom have been extensively used in Oriental medicine even though their effectiveness and safety profile is still controversial due to the limited evidence (Zhang et al., 2018).

In our days, the toxicity of BV it is a big dilemma for the researchers. Several authors reported that BV is safe for humans, allowing to take advantage of its antimicrobial (Uddin et al., 2016), anti-inflammatory, anti-wrinkle (Lee et al., 2015c), and anti-acne properties (Han et al., 2016a), among others. The topical application of BV is advantageous to the residual harmful systemic side effects (Nitecka-Buchta et al., 2014). On the other hand, several other studies raised concerns on BV toxicity (Lee et al., 2015c; Kołaczek et al., 2017). A meta-analysis performed in 2015, including 145 studies, revealed that the median frequency of patients experiencing adverse events associated with BV immunotherapy was $29 \%$ (in the audit studies); and BV acupuncture had a $261 \%$ increased relative risk for the occurrence of adverse events, in comparison with normal saline injection (Park et al., 2015). Systemic reactions occurred in $14 \%$ of the patients, half of which were severe. This study concluded that adverse events related to bee venom therapy are frequent, suggesting that safety is still a limitation to take into consideration.

Gülmez et al. (2017) reported that BV is highly toxic to cancer cells but also to non-tumorigenic cells, suggesting that the use of $\mathrm{BV}$ in the treatment of malignant tumours should be re-evaluated due to the undesirable cytotoxicity; further studies must be performed to clarify this issue.

Recently, a case reported raised a major issue. A Spanish women of 55 years age, without clinical records of any disorder, risk factors or previous reactions of any kind to Hymenoptera, had been attending apitherapy sessions for two years with good tolerance. One day, immediately after a live bee sting the women suddenly developed dyspnoea, wheezing and loss of consciousness and, due to multiorgan failure, died a few weeks later (Vazquez-Revuelta and MadrigalBurgaleta, 2018). According to the researchers this case is the first report of death associated to the BV therapy due to complications of severe anaphylaxis.

A recent in vivo study performed in 2018, using mice, reported that the approximate median lethal dose $\left(\mathrm{LD}_{50}\right)$ of the $\mathrm{BV}$ is $13.19 \mathrm{mg} / \mathrm{kg}$ (Lashein et al., 2018). The amount of BV released during a bee sting ranges between 50 and $140 \mu \mathrm{g}$ (Moreno and Giralt, 2015), much lower than the average lethal dose. However, as previously described, it may be sufficient to trigger an anaphylactic reaction. Therefore, for each therapeutic use the optimal dose and application method must be determined, in order to ensure that the beneficial effects are not hampered by harmful adverse reactions.

Last but not the least, it is essential to ensure the safety and quality of the BV: before use, a battery of physicochemical and microbiological analysis must be performed. Attention must be paid also on the storage conditions: BV may be stored up to 12 months at room temperature or up to 24 months if kept in a cool place $\left(2-8^{\circ} \mathrm{C}\right)$, in the original container, unopened, in a dry place and away from strong light (Lee et al., 2015a).

\section{Conclusions}

Bee venom has been used since the ancient times in the treatment of different disorders. On the last decades, several studies provided 
scientific evidence regarding the wide range of biological activities of Apitoxin. In spite of that, the adverse effects that not uncommonly follow BV administration are still a challenge for researchers and healthcare practitioners worldwide. Indeed, even though BV immunotherapy appears to be efficacious and safe (when used in controlled conditions), side effects related to BV therapy cannot be underscored. In addition, the generation of clinical-grade and sterile pharmaceutical products derived from BV is still challenging, mostly related to identification, isolation, and purification of bioactive components; further developments are expected. In the future, practitioners should be trained in order to optimize the BV concentrations that allow maximising the clinical beneficial effects while avoiding adverse ones; further studies (mainly randomized controlled trials) are required.

\section{Declaration of competing interest}

The authors declare that they have no known competing financial interests or personal relationships that could have appeared to influence the work reported in this paper.

\section{Acknowledgments}

A. Pascoal would like to thank Foundation for Science and Technology (FCT, Portugal), Programa Operacional Pontencial Humano (POPH) and European Union (EU) for his Postdoctoral grant SFRH/ BPD/91380/2012. The authors also are grateful to the Centre of Molecular and Environmental Biology, funded by FCT, UID/BIA/ 04050/2013 (POCI-01-0145-FEDER-007569) and by the ERDF through the COMPETE2020 - Programa Operacional Competitividade e Internacionalização (POCI).

\section{References}

Abd-Elhakim, Y.M., Khalil, S.R., Awad, A., Al-Ayadhi, L.Y., 2014. Combined cytogenotoxic effects of bee venom and bleomycin on rat lymphocytes: an in vitro study. BioMed Res. Int 2014. https://doi.org/10.1155/2014/173903.

Abd El-Wahed, A.A., Shaden, K., Sheikh, B.Y., Farag, M.A., Saeed, A., Larik, F.A., KocaCaliskan, U., AlAjmi, M.F., Hassan, M., Wahabi, H.A., Hegazy, M.E.F., Algethami, A.F., Buttner, S., El-Seedi, H.R., 2018. Bee venom composition: from chemistry to biological activity. Stud. Nat. Prod. Chem. 459-484. https://doi.org/10.1016/b9780-444-64181-6.00013-9.

Ahn, Y.J., Shin, J.S., Lee, J., Lee, Y.J., Kim, M.R., Shin, Y.S., ... Lee, H.D., 2016. Safety of essential bee venom pharmacopuncture as assessed in a randomized controlled double-blind trial. J. Ethnopharmacol. 194, 774-780. https://doi.org/10.1016/j.jep. 2016.11.012.

Al-Safar, M.A., Hassan, J.S., Abdulrhman, T.R., Kashkol, A.S., 2018. Antibacterial activity of bee venom against multidrug-resistant acinetobacter baumannii locally isolates. Int. J. Res. Pharm. Sci. 9 (4), 1510-1514.

Antolín-Amérigo, D., Ruiz-León, B., Boni, E., Alfaya-Arias, T., Álvarez-Mon, M., Barbarroja-Escudero, J., Vega-Castro, A., 2017. Component-resolved diagnosis in hymenoptera allergy. Allergol. Immunopathol. 46 (3), 253-262. https://doi.org/10. 1016/j.aller.2017.05.003.

Blank, S., Seismann, H., McIntyre, M., Ollert, M., Wolf, S., Bantleon, F.I., Spillner, E., 2013. Vitellogenins are new high molecular weight components and allergens (Api m 12 and Ves v 6) of Apis mellifera and Vespula vulgaris venom. PLoS One 8 (4). https://doi.org/10.1371/journal.pone.0062009.

Bordon, K.C., Wiezel, G.A., Amorim, F.G., Arantes, E.C., 2015. Arthropod venom Hyaluronidases: biochemical properties and potential applications in medicine and biotechnology. J. Venom. Anim. Toxins Incl. Trop. Dis. 21 (1), 43. https://doi.org/ 10.1186/s40409-015-0042-7.

Boutrin, M.C., Foster, H.A., Pentreath, V.W., 2008. The effects of bee (Apis mellifera) venom phospholipase $\mathrm{A}_{2}$ on Trypanosoma brucei brucei and enterobacteria. Exp Parasitol. 119 (2), 246-251. https://doi.org/10.1016/j.exppara.2008.02.002.

Brito, J.C.M.D., Bastos, E.M.A.F., Heneine, L.G.D., Figueiredo, K.C.D.S., 2018. Fractionation of Apis mellifera venom by means of ultrafiltration: removal of phospholipase $A_{2}$. Braz. J. Chem. Eng. 35 (1), 229-236. https://doi.org/10.1590/01046632.20180351s20160171.

Chen, J., Guan, S.M., Sun, W., Fu, H., 2016. Melittin, the major pain-producing substance of bee venom. Neurosci. Bull. 32 (3), 265-272. https://doi.org/10.1007/s12264-0160024-y.

Cherniack, E.P., Govorushko, S., 2018. To bee or not to bee: the potential efficacy and safety of bee venom acupuncture in humans. Toxicon 154, 74-78. https://doi.org/10. 1016/j.toxicon.2018.09.013.

Cho, H.J., Kang, J.H., Park, K.K., Choe, J.Y., Park, Y.Y., Moon, Y.S., ... Kim, W.J., 2013. Comparative proteome analysis of Tumor necrosis factor $\alpha$-stimulated human
Vascular Smooth Muscle Cells in response to melittin. Proteome Sci. 11 (1), 20. https://doi.org/10.1186/1477-5956-11-20.

Cho, S.Y., Lee, Y.E., Doo, K.H., Lee, J.H., Jung, W.S., Moon, S.K., ... Park, H.J., 2018. Efficacy of combined treatment with acupuncture and bee venom acupuncture as an adjunctive treatment for Parkinson's disease. J. Altern. Complement. Med. 24 (1), 25-32. https://doi.org/10.1089/acm.2016.0250.

Cho, S.Y., Park, J.Y., Jung, W.S., Moon, S.K., Park, J.M., Ko, C.N., Park, S.U., 2013a. Bee venom acupuncture point injection for central post stroke pain: a preliminary singleblind randomized controlled trial. Complement. Ther. Med. 21 (3), 155-157. https:// doi.org/10.1016/j.ctim.2013.02.001.

Choi, C.S., Park, J.K., An, C.G., Lee, E.H., Ahn, K.J., 2015. Multiple benefits of bee venom in aged skin manifestations. Kor J. Aesthet. Cosmetol. 13 (5), 679-688.

Choi, K.E., Hwang, C.J., Gu, S.M., Park, M.H., Kim, J.H., Park, J.H., ... Han, S.B., 2014. Cancer cell growth inhibitory effect of bee venom via increase of death receptor 3 expression and inactivation of NF-kappa B in NSCLC cells. Toxins 6 (8), 2210-2228. https://doi.org/10.3390/toxins6082210.

Cornara, L., Biagi, M., Xiao, J., Burlando, B., 2017. Therapeutic properties of bioactive compounds from different honeybee products. Front. Pharmacol. 8, 412. https://doi. org/10.3389/fphar.2017.00412.

Deregnaucourt, C., Schrével, J., 2000. Bee venom phospholipase $A_{2}$ induces stage-specific growth arrest of the intraerythrocytic Plasmodium falciparum via modifications of human serum components. J. Biol. Chem. 275 (51), 39973-39980.

Doo, A.R., Kim, S.N., Kim, S.T., Park, J.Y., Chung, S.H., Choe, B.Y., ... Park, H.J., 2012. Bee venom protects SH-SY5Y human neuroblastoma cells from 1-methyl-4-phenylpyridinium-induced apoptotic cell death. Brain Res. 1429, 106-115. https://doi. org/10.1016/j.brainres.2011.10.003.

dos Santos-Pinto, J.R.A., Perez-Riverol, A., Lasa, A.M., Palma, M.S., 2018. Diversity of peptidic and proteinaceous toxins from social Hymenoptera venoms. Toxicon 148, 172-196. https://doi.org/10.1016/j.toxicon.2018.04.029.

El-Wahab, S.D.A., Eita, L.H., 2015. The effectiveness of live bee stingý acupuncture on depression. IOSR J. Nurs. Health Sci. 4, 19-27. https://doi.org/10.9790/195904431927.

Eze, O.B., Nwodo, O.F., Ogugua, V.N., 2016. Therapeutic effect of honey bee venom. J. Pharm. Chem. Biol. Sci. 4 (1), 48-53.

Fenard, D., Lambeau, G., Maurin, T., Lefebvre, J.C., Doglio, A., 2001. A peptide derived from bee venom-secreted phospholipase $\mathrm{A}_{2}$ inhibits replication of T-cell tropic HIV-1 strains via interaction with the CXCR4 chemokine receptor. Mol. Pharmacol. 60 (2), 341-347. https://doi.org/10.1124/mol.60.2.341.

Gajski, G., Čimbora-Zovko, T., Rak, S., Osmak, M., Garaj-Vrhovac, V., 2016. Antitumour action on human glioblastoma A1235 cells through cooperation of bee venom and cisplatin. Cytotechnology 68 (4), 1197-1205. https://doi.org/10.1007/s10616-0159879-4.

Gu, H., An, H.-J., Kim, J.-Y., Kim, W.-H., Gwon, M.-G., Kim, H.-J., ... Park, K.-K., 2019. Bee venom attenuates Porphyromonas gingivalis and RANKL-induced bone resorption with osteoclastogenic differentiation. Food Chem. Toxicol. https://doi.org/10. 1016/j.fct.2019.05.001

Gülmez, Y., Aydın, A., Can, İ., Tekin, Ş., Cacan, E., 2017. Cellular toxicity and biological activities of honey bee (Apis mellifera L.) venom. Marmara Pharm. J. 21 (2), 251-260. https://doi.org/10.12991/marupj.300329.

Han, S.M., Hong, I.P., Woo, S.O., Chun, S.N., Park, K.K., Nicholls, Y.M., Pak, S.C., 2015. The beneficial effects of honeybee-venom serum on facial wrinkles in humans. Clin. Interv. Aging 10, 1587. https://doi.org/10.2147/CIA.S84940.

Han, S.M., Kim, J.M., Hong, I.P., Woo, S.O., Kim, S.G., Jang, H.R., Pak, S.C., 2016. Antibacterial activity and antibiotic-enhancing effects of honeybee venom against methicillin-resistant Staphylococcus aureus. Molecules 21 (1), 79. https://doi.org/ 10.3390/molecules21010079.

Han, S.M., Kim, J.M., Park, K.K., Chang, Y.C., Pak, S.C., 2014. Neuroprotective effects of melittin on hydrogen peroxide-induced apoptotic cell death in neuroblastoma SHSY5Y cells. BMC Complement Altern. Med. 14 (1), 286. https://doi.org/10.1186/ 1472-6882-14-286.

Han, S.M., Lee, K.G., Pak, S.C., 2013a. Effects of cosmetics containing purified honeybee (Apis mellifera L.) venom on acne vulgaris. J. Integr. Med. 11 (5), 320-326. https:// doi.org/10.3736/jintegrmed2013043.

Han, S.M., Pak, S.C., Nicholls, Y.M., Macfarlane, N., 2016a. Evaluation of anti-acne property of purified bee venom serum in humans. J. Cosmet. Dermatol. 15 (4), 324-329. https://doi.org/10.1111/jocd.12227.

Hassan, M.I., Mohamed, A.F., Amer, M.A., Hammad, K.M., Riad, S.A., 2015. Monitoring of the antiviral potential of bee venom and wax extracts against Adeno-7 (DNA) and Rift Valley fever virus (RNA) viruses models. J. Egypt. Soc. Parasitol. 45 (1), 193-198. https://doi.org/10.12816/0010865.

Hegazi, A.G., Allah, F.M.A., Saleh, A.A., Abdou, A.M., Fouad, E.A., 2017. Antibacterial activity of Italian (Apis mellifera) bees venom. J. Chem. Pharm. Sci. 10 (3).

Hood, J.L., Jallouk, A.P., Campbell, N., Ratner, L., Wickline, S.A., 2013. Cytolytic nanoparticles attenuate HIV-1 infectivity. Antivir. Ther. 18 (1), 95-103. https://doi. org/10.3851/IMP2346.

Hossen, M., Gan, S.H., Khalil, M., 2017. Melittin, a potential natural toxin of crude bee venom: probable future arsenal in the treatment of diabetes mellitus. J. Chem. 2017. https://doi.org/10.1155/2017/4035626.

Hossen, M., Shapla, U., Gan, S., Khalil, M., 2016. Impact of bee venom enzymes on diseases and immune responses. Molecules 22 (1), 25. https://doi.org/10.3390/ molecules 22010025 .

Hwang, D.S., Kim, S., Bae, H., 2015. Therapeutic effects of bee venom on immunological and neurological diseases. Toxins 7, 2413-2421. 7. https://doi.org/10.3390/ toxins7072413.

Ip, S.W., Chu, Y.L., Yu, C.S., Chen, P.Y., Ho, H.C., Yang, J.S., ... Chung, J.G., 2012. Bee venom induces apoptosis through intracellular $\mathrm{Ca} 2+$-modulated intrinsic death 
pathway in human bladder cancer cells. Int. J. Urol. 19 (1), 61-70. https://doi.org/ 10.1111/j.1442-2042.2011.02876.x.

Ip, S.W., Liao, S.S., Lin, S.Y., Lin, J.P., Yang, J.S., Lin, M.L., ... Chung, J.G., 2008. The role of mitochondria in bee venom-induced apoptosis in human breast cancer MCF7 cells. In Vivo 22 (2), 237-245.

Jakob, T., Müller, U., Helbling, A., Spillner, E., 2017. Component resolved diagnostics for hymenoptera venom allergy. Curr. Opin. Allergy Clin. Immunol. 17 (5), 363-372. https://doi.org/10.1097/ACI.0000000000000390.

Jallouk, A.P., Moley, K.H., Omurtag, K., Hu, G., Lanza, G.M., Wickline, S.A., Hood, J.L., 2014. Nanoparticle incorporation of melittin reduces sperm and vaginal epithelium cytotoxicity. PLoS One 9 (4), e95411. https://doi.org/10.1371/journal.pone. 0095411.

Jang, M.H., Shin, M.C., Lim, S., Han, S.M., Park, H.J., Shin, I., ... Kim, C.J., 2003. Bee venom induces apoptosis and inhibits expression of cyclooxygenase-2 mRNA in human lung cancer cell line NCI-H1299. J. Pharmacol. Sci. 91 (2), 95-104. https:// doi.org/10.1254/jphs.91.95.

Jeong, J.K., Moon, M.H., Bae, B.C., Lee, Y.J., Seol, J.W., Park, S.Y., 2011. Bee venom phospholipase $\mathrm{A}_{2}$ prevents prion peptide induced-cell death in neuronal cells. Int. J. Mol. Med. 28 (5), 867-873. https://doi.org/10.3892/ijmm.2011.730.

Jeong, Y.J., Cho, H.J., Whang, K., Lee, I.S., Park, K.K., Choe, J.Y., ... Kim, W.J., 2012. Melittin has an inhibitory effect on TNF- $\alpha$-induced migration of human aortic smooth muscle cells by blocking the MMP-9 expression. Food Chem. Toxicol. 50 (11), 3996-4002. https://doi.org/10.1016/j.fct.2012.08.026.

Jeong, Y.J., Choi, Y., Shin, J.M., Cho, H.J., Kang, J.H., Park, K.K., ... Chang, H.W., 2014. Melittin suppresses EGF-induced cell motility and invasion by inhibiting PI3K/Akt/ mTOR signaling pathway in breast cancer cells. Food Chem. Toxicol. 68, 218-225. https://doi.org/10.1016/j.fct.2014.03.022.

Jeong, Y.J., Shin, J.M., Bae, Y.S., Cho, H.J., Park, K.K., Choe, J.Y., ... Kim, C.H., 2015. Melittin has a chondroprotective effect by inhibiting MMP-1 and MMP-8 expressions via blocking NF- $\mathrm{KB}$ and AP-1 signaling pathway in chondrocytes. Int.

Immunopharmacol. 25 (2), 400-405. https://doi.org/10.1016/j.intimp.2015.02.021.

Jin, Z., Yao, J., Xie, N., Cai, L., Qi, S., Zhang, Z., Li, B., 2018. Melittin constrains the expression of identified key genes associated with bladder cancer. J. Immunol. Res 2018. https://doi.org/10.1155/2018/5038172.

Jo, M., Park, M.H., Kollipara, P.S., An, B.J., Song, H.S., Han, S.B., ... Hong, J.T., 2012. Anti-cancer effect of bee venom toxin and melittin in ovarian cancer cells through induction of death receptors and inhibition of JAK2/STAT3 pathway. Toxicol. Appl. Pharmacol. 258 (1), 72-81. https://doi.org/10.1016/j.taap.2011.10.009.

Jung, G.B., Huh, J.E., Lee, H.J., Kim, D., Lee, G.J., Park, H.K., Lee, J.D., 2018. Anti-cancer effect of bee venom on human MDA-MB-231 breast cancer cells using Raman spectroscopy. Biomed. Opt. Express 9 (11), 5703-5718. https://doi.org/10.1364/BOE.9. 005703.

Jung, S., Lee, C., Yeo, I., Sung, H., Roh, J., Jo, N., Lee, E., 2014. A case study of 20 patients with lateral epicondylitis of the elbow by using hwachim (burning acupuncture therapy) and sweet bee venom pharmacopuncture. J. Pharmacopuncture 17 (4), 22. https://doi.org/10.3831/KPI.2014.17.033.

Jung, S.Y., Lee, K.W., Choi, S.M., Yang, E.J., 2015. Bee venom protects against rotenoneinduced cell death in NSC34 motor neuron cells. Toxins 7 (9), 3715-3726. https:// doi.org/10.3390/toxins7093715.

Kachel, H.S., Buckingham, S.D., Sattelle, D.B., 2018. Insect toxins-selective pharmacological tools and drug/chemical leads. Current opinion in insect science. https://doi. org/10.1016/j.cois.2018.10.001.

Kim, H.J., Jeon, B.S., 2014. Is acupuncture efficacious therapy in Parkinson's disease? J. Neurol. Sci. 341 (1-2), 1-7. https://doi.org/10.1016/j.jns.2014.04.016.

Kim, J.M., Jeon, H.J., Kim, H.J., Cho, C.K., Yoo, H.S., 2014. Bee venom pharmacopuncture: an effective treatment for complex regional pain syndrome. J. Pharmacopuncture 17 (4), 66. https://doi.org/10.3831/KPI.2014.17.039.

Kim, J.Y., Lee, W.R., Kim, K.H., An, H.J., Chang, Y.C., Han, S.M., ... Park, K.K., 2015. Effects of bee venom against Propionibacterium acnes-induced inflammation in human keratinocytes and monocytes. Int. J. Mol. Med. 35 (6), 1651-1656. https:// doi.org/10.3892/ijmm.2015.2180.

Kim, W.H., An, H.J., Kim, J.Y., Gwon, M.G., Gu, H., Jeon, M., ... Park, K.K., 2018. Antiinflammatory effect of melittin on Porphyromonas gingivalis LPS-stimulated human keratinocytes. Molecules 23 (2), 332. https://doi.org/10.3390/molecules23020332.

Kim, W.H., An, H.J., Kim, J.Y., Gwon, M.G., Gu, H., Lee, S.J., ... Park, K.K., 2017a. Apamin inhibits TNF-a-and IFN-g-induced inflammatory cytokines and chemokines via suppressions of NF-kB signaling pathway and STAT in human keratinocytes. Pharmacol. Rep. 69, 1030-1035. https://doi.org/10.1016/j.pharep.2017.04.006.

Kim, J., An, H., Kim, W., Park, Y., Park, K.D., Park, K., 2017b. Apamin suppresses biliary fibrosis and activation of hepatic stellate cells. Int. J. Mol. Med. 39, 1188-1194. https://doi.org/10.3892/ijmm.2017.2922.

Kim, W.H., An, H.J., Kim, J.Y., Gwon, M.G., Gu, H., Park, J.B., ... Park, K.K., 2016. Bee venom inhibits porphyromonas gingivalis lipopolysaccharides-induced pro-inflammatory cytokines through suppression of NF-KB and AP-1 signaling pathways. Molecules 21 (11), 1508. https://doi.org/10.3390/molecules21111508.

Kim, Y.W., Chaturvedi, P.K., Chun, S.N., Lee, Y.G., Ahn, W.S., 2015a. Honeybee venom possesses anticancer and antiviral effects by differential inhibition of HPV E6 and E7 expression on cervical cancer cell line. Oncol. Rep. 33 (4), 1675-1682. https://doi. org/10.3892/or.2015.3760.

Kołaczek, A., Skorupa, D., Antczak-Marczak, M., Kuna, P., Kupczyk, M., 2017. Safety and efficacy of venom immunotherapy: a real life study. Adv. Dermatol. Allergol./Postępy Dermatologii i Alergologii 34 (2), 159. https://doi.org/10.5114/ada.2017.67082.

Komi, D.E.A., Shafaghat, F., Zwiener, R.D., 2018. Immunology of bee venom. Clin. Rev. Allergy Immunol. 54 (3), 386-396. https://doi.org/10.1007/s12016-017-8597-4.

Kong, G.M., Tao, W.H., Diao, Y.L., Fang, P.H., Wang, J.J., Bo, P., Qian, F., 2016. Melittin induces human gastric cancer cell apoptosis via activation of mitochondrial pathway.
World J. Gastroenterol. 22 (11), 3186. https://doi.org/10.3748/wjg.v22.i11.3186. Lashein, F.E.D.M., Amra, E.S.A., Seleem, A.A., Badr, A.H., 2018. Ameliorative effect of bee venom and its extracted bradykinin-potentiating factor on neurological alteration induced by acrylamide and chips administration. J. Basic Appl. Zool. 79 (1). https:// doi.org/10.1186/s41936-018-0048-0.

Leandro, L.F., Mendes, C.A., Casemiro, L.A., Vinholis, A.H., Cunha, W.R., Almeida, R.D., Martins, C.H., 2015. Antimicrobial activity of BV, melittin and phospholipase $A_{2}$ of honey bee (Apis mellifera) venom against oral pathogens. An Acad. Bras Ciências 87 (1), 147-155. https://doi.org/10.1590/0001-3765201520130511.

Lee, G., Bae, H., 2016. Anti-Inflammatory applications of melittin, a major component of bee venom: detailed mechanism of action and adverse effects. Molecules 21 (5), 616. https://doi.org/10.3390/molecules21050616.

Lee, H., Pyo, M.J., Bae, S.K., Heo, Y., Kim, C.G., Kang, C., Kim, E., 2015c. Improved therapeutic profiles of PLA P $_{2}$-free bee venom prepared by ultrafiltration method. Toxicol. Res. 31 (1), 33. https://doi.org/10.5487/TR.2015.31.1.033.

Lee, H.J., Park, I.S., Lee, J.I., Kim, J.S., 2015a. Guillain-Barre syndrome following bee venom acupuncture. Intern. Med. 54 (8), 975-978. https://doi.org/10.2169/ internalmedicine.54.2238.

Lee, H.L., Park, S.H., Kim, T.M., Jung, Y.Y., Park, M.H., Oh, S.H., ... Lee, U.S., 2015b. Bee venom inhibits growth of human cervical tumors in mice. Oncotarget 6 (9), 7280 https://doi.org/10.18632/oncotarget.3110.

Lee, K.S., Kim, B.Y., Yoon, H.J., Choi, Y.S., Jin, B.R., 2016. Secapin, a bee venom peptide, exhibits anti-fibrinolytic, anti-elastolytic, and anti-microbial activities. Dev. Comp. Immunol. 63, 27-35. https://doi.org/10.1016/j.dci.2016.05.011.

Lee, P., Yu, J., 2014. Sweet bee venom pharmacopuncture may be effective for treating sexual dysfunction. J. Pharmacopuncture 17 (3), 70. https://doi.org/10.3831/KPI. 2014.17.029.

Lee, S.B., 2016. Antifungal activity of bee venom and sweet bee venom against clinically isolated Candida albicans. J. Pharmacopuncture 19 (1), 45. https://doi.org/10.3831/ KPI.2016.19.006.

Lee, S.H., Hong, S.J., Kim, S.Y., Yang, H.I., Lee, J.D., Choi, D.Y., Lee, D.I., Lee, Y.H., 2003. Randomized controlled double blind study of bee venom therapy on rheumatoid arthritis. J. Korean Acupunct. Moxib. Soc. 20, 80-88.

Lee, S.H., Kwon, G.S., Kang, M.S., Yoon, H.M., Kim, C.H., 2012. Comparative study on the effects of bee venom pharmacopuncture according to the treatment method for knee osteoarthritis. J. Pharmacopuncture 15 (4), 7. https://doi.org/10.3831/KPI.2012.15. 011.

Lee, S.H., Lee, H.J., Baek, Y.H., Kim, S.Y., Park, J.K., Hong, S.J., ... Lee, D.I., 2003a Effects of Bee Venom on the pain, edema, and acute inflammatory reactant of Rheumatoid Arthritis patients. J. Korean Acupunct. Moxibustion Soc. 20 (2), 77-84.

Lee, S.M., Lim, J., Lee, J.D., Choi, D.Y., Lee, S., 2014a. Bee venom treatment for refractory postherpetic neuralgia: a case report. J. Altern. Complement. Med. 20 (3), 212-214. https://doi.org/10.1089/acm.2013.0130.

Lee, W.R., Kim, K.H., An, H.J., Kim, J.Y., Han, S.M., Lee, K.G., Park, K.K., 2014. Protective effect of melittin against inflammation and apoptosis on Propionibacterium acnesinduced human THP-1 monocytic cell. Eur. J. Pharmacol. 740, 218-226. https://doi. org/10.1016/j.ejphar.2014.06.058.

Lee, W.R., Pak, S., Park, K.K., 2015. The protective effect of bee venom on fibrosis causing inflammatory diseases. Toxins 7 (11), 4758-4772. https://doi.org/10.3390/ toxins7114758.

Lee, Y., Kim, S.G., Kim, I.S., Lee, H.D., 2018. Standardization of the manufacturing process of bee venom pharmacopuncture containing melittin as the active ingredient. Evidence-based complementary and alternative medicine. https://doi.org/10.1155/ 2018/2353280.

Li, B., Gu, W., Zhang, C., Huang, X.Q., Han, K.Q., Ling, C.Q., 2006. Growth arrest and apoptosis of the human hepatocellular carcinoma cell line BEL-7402 induced by melittin. Oncol. Res. Treat. 29 (8-9), 367-371. https://doi.org/10.1159/000094711.

Li, W.F., Ma, G.X., Zhou, X.X., 2006a. Apidaecin-type peptides: biodiversity, structurefunction relationships and mode of action. Peptides 27 (9), 2350-2359. https://doi. org/10.1016/j.peptides.2006.03.016.

Liu, C.C., Hao, D.J., Zhang, Q., An, J., Zhao, J.J., Chen, B., ... Yang, H., 2016. Application of bee venom and its main constituent melittin for cancer treatment. Cancer Chemother. Pharmacol. 78 (6), 1113-1130. https://doi.org/10.1007/s00280-0163160-1.

Liu, M., Wang, H., Liu, L., Wang, B., Sun, G., 2016a. Melittin-MIL-2 fusion protein as a candidate for cancer immunotherapy. J. Transl. Med. 14 (1), 155. https://doi.org/10 1186/s12967-016-0910-0.

Mahmoodzadeh, A., Zarrinnahad, H., Bagheri, K.P., Moradia, A., Shahbazzadeh, D., 2015. First report on the isolation of melittin from Iranian honey bee venom and evaluation of its toxicity on gastric cancer AGS cells. J. Chin. Med. Assoc. 78 (10), 574-583. https://doi.org/10.1016/j.jcma.2015.06.008.

Marković-Housley, Z., Miglierini, G., Soldatova, L., Rizkallah, P.J., Müller, U., Schirmer, T., 2000. Crystal structure of hyaluronidase, a major allergen of bee venom. Structure 8 (10), 1025-1035. https://doi.org/10.1016/S0969-2126(00)00511-6.

Moga, M., Dimienescu, O., Arvătescu, C., Ifteni, P., Pleş, L., 2018. Anticancer activity of toxins from bee and snake venom-an overview on ovarian cancer. Molecules 23 (3), 692. https://doi.org/10.3390/molecules23030692.

Mohammadi, E., Vatanpour, H., Shirazi, F.H., 2015. Immunomodulatory effects of bee venom in human synovial fibroblast cell line. Iran. J. Pharm. Res. (IJPR): IJPR 14 (1), 313.

Mohseni-Kouchesfahani, H., Nabioni, M., Khosravi, Z., Rahimi, M., 2017. Honeybee venom combined with 1, 25-dihydroxyvitamin D3as a highly efficient inducer of differentiation in human acute myeloid leukemia cells. J. Cancer Res. Ther. 13 (3), 544. https://doi.org/10.4103/0973-1482.183220.

Moon, D.O., Park, S.Y., Heo, M.S., Kim, K.C., Park, C., Ko, W.S., ... Kim, G.Y., 2006. Key regulators in bee venom-induced apoptosis are Bcl-2 and caspase- 3 in human 
leukemic U937 cells through downregulation of ERK and Akt. Int. Immunopharmacol. 6 (12), 1796-1807. https://doi.org/10.1016/j.intimp.2006.07. 027.

Moreno, M., Giralt, E., 2015. Three valuable peptides from bee and wasp venoms for therapeutic and biotechnological use: melittin, apamin and mastoparan. Toxins 7 (4), 1126-1150. https://doi.org/10.3390/toxins7041126.

Nguyen, H.V., Heger, Z., Kominkova, M., Michalek, P., Gumulec, J., Guran, R., ... Kizek, R., 2015. The electrochemical and statistical evaluation of isolation of mellitin and apamin from honey bee (Apis Mellifera) venom. Int. J. Electrochem. Sci. 10 (2015). http://www.electrochemsci.org/papers/vol10/100201249.pdf.

Nitecka-Buchta, A., Buchta, P., Tabeńska-Bosakowska, E., Walczyńska-Dragoń, K., Baron, S., 2014. Myorelaxant Effect of bee venom topical skin application in patients with RDC/TMD Ia and RDC/TMD Ib: a randomized, double blinded study. BioMed Res. Int. (2014). https://doi.org/10.1155/2014/296053.

Oršolić, N., 2009. Potentiation of Bleomycin lethality in HeLa and V79 cells by bee venom. Arh. Hig. Rada. Toksikol. 60 (3), 317-326. https://doi.org/10.2478/100041254-60-2009-1936.

Ostrovsky, D.A., Ehrlich, A., 2018. Bee venom acupuncture in addition to antiParkinsonian medications may improve activities of daily living and motor symptoms more than medication alone in idiopathic Parkinson's disease. Explore (New York, NY. https://doi.org/10.1016/j.explore.2018.10.013.

Park, J., Kwon, O., An, H.J., Park, K.K., 2018. Antifungal effects of bee venom components on trichophyton rubrum: a novel approach of bee venom study for possible emerging antifungal agent. Ann. Dermatol. 30 (2), 202-210. https://doi.org/10. 5021/ad.2018.30.2.202.

Park, J.H., Jeong, Y.J., Park, K.K., Cho, H.J., Chung, I.K., Min, K.S., ... Chang, Y.C., 2010. Melittin suppresses PMA-induced tumor cell invasion by inhibiting NF-KB and AP-1dependent MMP-9 expression. Mol. Cells 29 (2), 209-215. https://doi.org/10.1007/ s10059-010-0028-9.

Park, J.H., Lee, W.R., Kim, H.S., Han, S.M., Chang, Y.C., Park, K.K., 2014. Protective effects of melittin on tumour necrosis factor- $\alpha$ induced hepatic damage through suppression of apoptotic pathway and nuclear factor-kappa B activation. Exp. Biol. Med. 239 (12), 1705-1714. https://doi.org/10.1177/1535370214533880.

Park, J.H., Yim, B.K., Lee, J.H., Lee, S., Kim, T.H., 2015. Risk associated with bee venom therapy: a systematic review and meta-analysis. PLoS One 10 (5), e0126971. https:// doi.org/10.1371/journal.pone.0126971.

Park, J.S., Lee, M.J., Chung, K.H., Ko, D.K., Chung, H., 2013. Live bee acupuncture (B ong-C him) dermatitis: dermatitis due to live bee acupuncture therapy in $\mathrm{K}$ orea. Int. J. Dermatol. 52 (12), 1519-1524. https://doi.org/10.1111/ijd.12161.

Park, J.W., Jeon, J.H., Yoon, J., Jung, T.Y., Kwon, K.R., Cho, C.K., ... Yoo, H.S., 2012. Effects of sweet bee venom pharmacopuncture treatment for chemotherapy-induced peripheral neuropathy: a case series. Integr. Cancer Ther. 11 (2), 166-171. https:// doi.org/10.1177/1534735411413265.

Park, M.H., Choi, M.S., Kwak, D.H., Oh, K.W., Yoon, D.Y., Han, S.B., ... Hong, J.T., 2011. Anti-cancer effect of bee venom in prostate cancer cells through activation of caspase pathway via inactivation of NF-кB. The Prostate 71 (8), 801-812. https://doi.org/10. 1002/pros.21296.

Prakash, S., Bhargava, H.R., 2014. Apis cerana bee venom: it's antidiabetic and antidandruff activity against Malassezia furfur. World Appl. Sci. J. 32 (3), 343-348.

Rady, I., Siddiqui, I.A., Rady, M., Mukhtar, H., 2017. Melittin, a major peptide component of bee venom, and its conjugates in cancer therapy. Cancer Lett. 402, 16-31. https:// doi.org/10.1016/j.canlet.2017.05.010.

Ratcliffe, N., Azambuja, P., Mello, C.B., 2014. Recent advances in developing insect natural products as potential modern day medicines. Evidence-based complementary and alternative medicine. https://doi.org/10.1155/2014/904958 2014.

Reitinger, S., Boroviak, T., Laschober, G.T., Fehrer, C., Müllegger, J., Lindner, H., Lepperdinger, G., 2008. High-yield recombinant expression of the extremophile enzyme, bee hyaluronidase in Pichia pastoris. Protein Expr. Purif. 57 (2), 226-233. https://doi.org/10.1016/j.pep.2007.10.001.

Safaeinejad, Z., Nabiuni, M., Nazari, Z., 2013. Potentiation of a novel palladium (II) complex lethality with bee venom on the human T-cell acute lymphoblastic leukemia cell line (MOLT-4). J. Venom. Anim. Toxins Incl. Trop. Dis. 19 (1), 25. https://doi. org/10.1186/1678-9199-19-25.

Saini, S.S., Chopra, A.K., Peterson, J.W., 1999. Melittin activates endogenous phospholipase D during cytolysis of human monocytic leukemia cells. Toxicon 37 (11), 1605-1619. https://doi.org/10.1016/S0041-0101(99)00110-5.

Seo, B.K., Han, K., Kwon, O., Jo, D.J., Lee, J.H., 2017. Efficacy of bee venom acupuncture for chronic low back pain: a randomized, double-blinded, sham-controlled trial. Toxins 9 (11), 361. https://doi.org/10.3390/toxins9110361.

Shi, W., Li, C., Li, M., Zong, X., Han, D., Chen, Y., 2016. Antimicrobial peptide melittin against Xanthomonas oryzae pv. oryzae, the bacterial leaf blight pathogen in rice. Appl. Microbiol. Biotechnol. 100 (11), 5059-5067. https://doi.org/10.1007/s00253016-7400-4.

Shin, B.C., Kong, J.C., Park, T.Y., Yang, C.Y., Kang, K.W., Choi, S.M., 2012. Bee venom acupuncture for chronic low back pain: a randomised, sham-controlled, triple-blind clinical trial. Eur. J. Integr. Med. 4 (3), e271-e280. https://doi.org/10.1016/j.eujim. 2012.02.005

Shin, J.M., Jeong, Y.J., Cho, H.J., Park, K.K., Chung, I.K., Lee, I.K., ... Kim, W.J., 2013. Melittin suppresses HIF-1 $\alpha$ /VEGF expression through inhibition of ERK and mTOR/ p70S6K pathway in human cervical carcinoma cells. PLoS One 8 (7), e69380. https://doi.org/10.1371/journal.pone.0069380.

Shin, S.H., Ye, M.K., Choi, S.Y., Park, K.K., 2017. The effects of melittin and apamin on airborne fungi-induced chemical mediator and extracellular matrix production from nasal polyp fibroblasts. Toxins 9 (11), 348. https://doi.org/10.3390/toxins9110348.

Silva, J., Monge-Fuentes, V., Gomes, F., Lopes, K., Anjos, L., Campos, G., ... Campos, L., 2015. Pharmacological alternatives for the treatment of neurodegenerative disorders: wasp and bee venoms and their components as new neuroactive tools. Toxins 7 (8), 3179-3209. https://doi.org/10.3390/toxins7083179.

Sisakht, M., Mashkani, B., Bazi, A., Ostadi, H., Zare, M., Avval, F.Z., ... Soukhtanloo, M., 2017. Bee venom induces apoptosis and suppresses matrix metaloprotease- 2 expression in human glioblastoma cells. Rev. Bras. Farmacogn. 27 (3), 324-328. https://doi.org/10.1016/j.bjp.2016.11.006.

Sobral, F., Sampaio, A., Falcão, S., Queiroz, M.J.R., Calhelha, R.C., Vilas-Boas, M., Ferreira, I.C., 2016. Chemical characterization, antioxidant, anti-inflammatory and cytotoxic properties of bee venom collected in Northeast Portugal. Food Chem. Toxicol. 94, 172-177. https://doi.org/10.1016/j.fct.2016.06.008.

Somwongin, S., Chantawannakul, P., Chaiyana, W., 2018. Antioxidant activity and irritation property of venoms from Apis species. Toxicon 145, 32-39. https://doi.org/10. 1016/j.toxicon.2018.02.049.

Son, D.J., Lee, J.W., Lee, Y.H., Song, H.S., Lee, C.K., Hong, J.T., 2007. Therapeutic application of anti-arthritis, pain-releasing, and anti-cancer effects of bee venom and its constituent compounds. Pharmacol. Ther. 115 (2), 246-270. https://doi.org/10. 1016/j.pharmthera.2007.04.004.

Su, M., Chang, W., Cui, M., Lin, Y., Wu, S., Xu, T., 2015. Expression and anticancer activity analysis of recombinant human uPA1-43-melittin. Int. J. Oncol. 46 (2), 619-626. https://doi.org/10.3892/ijo.2014.2750.

Tosteson, M.T., Holmes, S.J., Razin, M., Tosteson, D.C., 1985. Melittin lysis of red cells. The Journal of membrane biology 87 (1), 35-44.

Tu, W.C., Wu, C.C., Hsieh, H.L., Chen, C.Y., Hsu, S.L., 2008. Honeybee venom induce calcium-dependent but caspase-independent apoptotic cell death in human melanoma A2058 cells. Toxicon 52 (2), 318-329. https://doi.org/10.1016/j.toxicon. 2008.06.007.

Tusiimire, J., Wallace, J., Dufton, M., Parkinson, J., Clements, C.J., Young, L., ... Watson, D.G., 2015. An LCMS method for the assay of melittin in cosmetic formulations containing bee venom. Anal. Bioanal. Chem. 407 (13), 3627-3635. https://doi.org/ 10.1007/s00216-015-8578-5.

Uddin, M.B., Lee, B.H., Nikapitiya, C., Kim, J.H., Kim, T.H., Lee, H.C., ... Kim, C.J., 2016. Inhibitory effects of bee venom and its components against viruses in vitro and in vivo. J. Microbiol. 54 (12), 853-866. https://doi.org/10.1007/s12275-016-6376-1.

Van Vaerenbergh, M., Cardoen, D., Formesyn, E.M., Brunain, M., Van Driessche, G., Blank, S., ... Devreese, B., 2013. Extending the honeybee venome with the antimicrobial peptide apidaecin and a protein resembling wasp antigen 5. Insect Mol. Biol. 22 (2), 199-210. https://doi.org/10.1111/imb.12013.

Varanda, E.A., Monti, R., Tavares, D.C., 1999. Inhibitory effect of propolis and bee venom on the mutagenicity of some direct-and indirect-acting mutagens. Teratog. Carcinog. Mutagen. 19 (6), 403-413. https://doi.org/10.1002/(sici)1520-6866(1999) 19:6 < 403::aid-tcm4 > 3.3.co;2-u https://search.crossref.org/?q = Varanda\%2C + E. A. $\% 2$ C + Monti $\% 2 C+$ R. $\% 2 C+\% 26+$ Tavares $\% 2 C+$ D.C. $+\% 281999 \% 29$. + Inhibitory + effect + of + propolis + and + bee + venom + on + the + mutagenicity + of + some + direct $\% \mathrm{E} 2 \% 80 \% 90$ and + indirect $\% \mathrm{E} 2 \% 80 \% 90$ acting + mutagens.

Vazquez-Revuelta, P., Madrigal-Burgaleta, R., 2018. Death due to live bee acupuncture apitherapy. J. Investig Allergol. Clin. Immunol. 28 (1), 45-46.

Vick, J.A., Shipman, W.H., 1972. Effects of whole bee venom and its fractions (apamin and melittin) on plasma cortisol levels in the dog. Toxicon 10 (4), 377-380. https:// doi:10.1016/0041-0101(72)90061-x.

Vick, J.A., Shipman, W.H., Brooks Jr., R., 1974. Beta adrenergic and anti-arrhythmic effects of cardiopep, a newly isolated substance from whole bee venom. Toxicon 12 (2), 139-142. https://doi.org/10.1016/0041-0101(74)90237-2.

Voos, P., Yazar, M., Lautenschläger, R., Rauh, O., Moroni, A., Thiel, G., 2017. The small neurotoxin apamin blocks not only small conductance $\mathrm{Ca} 2+$ activated $\mathrm{K}+$ channels (SK type) but also the voltage dependent Kv1. 3 channel. Eur. Biophys. J. 46 (6), 517-523. https://doi.org/10.1007/s00249-016-1196-0.

Wachinger, M., Kleinschmidt, A., Winder, D., von Pechmann, N., Ludvigsen, A., Neumann, M., ... Brack-Werner, R., 1998. Antimicrobial peptides melittin and cecropin inhibit replication of human immunodeficiency virus 1 by suppressing viral gene expression. J. Gen. Virol. 79 (4), 731-740. https://doi.org/10.1099/0022-131779-4-731.

Wang, C., Chen, T., Zhang, N., Yang, M., Li, B., Lü, X., ... Ling, C., 2009. Melittin, a major component of bee venom, sensitizes human hepatocellular carcinoma cells to tumor necrosis factor-related apoptosis-inducing ligand (TRAIL)-induced apoptosis by activating CaMKII-TAK1-JNK/p38 and inhibiting IкBa kinase-NFkB. J. Biol. Chem. 284 (6), 3804-3813.

Wang, W.H., Ahn, K.B., Lim, J.K., Jang, H.S., 2002. Clinical investigation compared with the effects of the bee-venom acupuncture on knee joint with osteoarthritis. J. Pharmacopuncture 4, 101-103.

Wang, X., Xie, J., Lu, X., Li, H., Wen, C., Huo, Z., ... Peng, C., 2017. Melittin inhibits tumor growth and decreases resistance to gemcitabine by downregulating cholesterol pathway gene CLU in pancreatic ductal adenocarcinoma. Cancer Lett. 399, 1-9. https://doi.org/10.1016/j.canlet.2017.04.012.

Wang, X., Xiong, L., Yu, G., Li, D., Peng, T., Luo, D., Xu, J., 2015. Cathepsin S silencing induces apoptosis of human hepatocellular carcinoma cells. Am. J. Tourism Res. 7 (1), 100. www.ajtr.org./ISSN:1943-8141/AJTR0003223.

Wehbe, R., Frangieh, J., Rima, M., El Obeid, D., Sabatier, J.-M., Fajloun, Z., 2019. Bee Venom: Overview of Main Compounds and Bioactivities for Therapeutic Interests. Molecules 24 (16), 2997. https://doi.org/10.3390/molecules24162997.

Yang, J., Lee, K.S., Kim, B.Y., Choi, Y.S., Yoon, H.J., Jia, J., Jin, B.R., 2017. Anti-fibrinolytic and anti-microbial activities of a serine protease inhibitor from honeybee (Apis cerana) venom. Comp. Biochem. Physiol. C Toxicol. Pharmacol. 201, 11-18. https://doi.org/10.1016/j.cbpc.2017.09.001.

Yang, Z.L., Ke, Y.Q., Xu, R.X., Peng, P., 2007. In: Melittin Inhibits Proliferation and Induces Apoptosis of Malignant Human Glioma Cells, vol. 27. Nan fang yi ke da xue xue bao = Journal of Southern Medical University, pp. 1775-1777 11. 
Yoon, J., Jeon, J.H., Lee, Y.W., Cho, C.K., Kwon, K.R., Shin, J.E., ... Yoo, H.S., 2012. Sweet bee venom pharmacopuncture for chemotherapy-induced peripheral neuropathy. J. Acupunct. Meridian Stud. 5 (4), 156-165. https://doi.org/10.1016/j.jams.2012.05. 003.

Zarrinnahad, H., Mahmoodzadeh, A., Hamidi, M.P., Mahdavi, M., Moradi, A., Bagheri, K.P., Shahbazzadeh, D., 2018. Apoptotic effect of melittin purified from Iranian honey bee venom on human cervical cancer HeLa cell line. Int. J. Pept. Res. Ther. 24 (4), 563-570. https://doi.org/10.1007/s10989-017-9641-1.

Zhang, H., Zhao, B., Huang, C., Meng, X.M., Bian, E.B., Li, J., 2014. Melittin restores PTEN expression by down-regulating HDAC2 in human hepatocelluar carcinoma HepG2 cells. PLoS One 9 (5), e95520. https://doi.org/10.1371/journal.pone.0095520.
Zhang, S., Liu, Y., Ye, Y., Wang, X.R., Lin, L.T., Xiao, L.Y., ... Liu, C.Z., 2018. Bee venom therapy: potential mechanisms and therapeutic applications. Toxicon 148, 1-73. https://doi.org/10.1016/j.toxicon.2018.04.012.

Zhang, S.F., Chen, Z., 2017. Melittin exerts an antitumor effect on non-small cell lung cancer cells. Mol. Med. Rep. 16 (3), 3581-3586. https://doi.org/10.3892/mmr.2017. 6970.

Zhang, Z., Zhang, H., Peng, T., Li, D., Xu, J., 2016. Melittin suppresses cathepsin S-induced invasion and angiogenesis via blocking of the VEGF-A/VEGFR-2/MEK1/ERK1/ 2 pathway in human hepatocellular carcinoma. Oncol. lett. 11 (1), 610-618. https:// doi.org/10.3892/ol.2015.3957. 